JKM (Jurnal Kebidanan Malahayati),Vol 7,No.3.Juli 2021,

ISSN (Print) 2476-8944 ISSN (Online) 2579-762X, Hal 413-420

\title{
FAKTOR FAKTOR YANG MEMPENGARUHI PENGGUNAAN ALAT KONTRASEPSI PADA SUAMI
}

\author{
Endang Murniasih* \\ *Sekolah Tinggi Ilmu Kesehatan Panca Bhakti Bandar Lampung \\ Email : endang@pancabhakti.ac.id
}

\section{ABSTRACT FACTORS AFFECTING THE USE OF CONTRACEPTIVE TOOLS TO HUSBAND}

Background the Family Planning Program (KB) has been established since 1970, together with the establishment of the National Family Planning Coordinating Board (BKKBN). The number of active family planning participants of husbands in Lampung Province tended to be low, namely $0.74 \%$ in MOP and $1.95 \%$ in condom users. The number of contraceptive users of husbands at Pinang Jaya Health Center is only $0.3 \%$. The purpose of this study is to know the influence factor factor to users of contraception on husbands at Pinang Jaya Health Center Bandar Lampung City in 2018.

Method of research used in this study is analytic observational and cross sectional design. Population is fertile age couples (PUS) in Pinang Jaya health centers as much as 987. Samples are counted as much as 312. Data collection techniques use primary data and data analysis using chi square and multiple logistic regression processed with computer programs.

Results showed the use of contraception of husbands at Pinang Jaya Public Health Center in Bandar Lampung City $44.2 \%$, good knowledge $50.6 \%$, positive attitude $45.5 \%$, higher education $60.3 \%$, The results of hypothesis testing indicate there is influence of knowledge $(p=0,000 ; O R=7.77)$, attitude $(p=0,000 ; O R=8,01)$, education $(p=0,000 ; O R=5,96)$ with the use of contraceptives of husbands. from these factors it is known that knowledge is the most dominant factor ( $p=0,000$ and $O R=4,380)$.

Conclusion The most dominant factor influencing the use of contraceptives by husbands at the Pinang Jaya Health Center Bandar Lampung City is the knowledge variable $(p=0.000$ and $O R=4.380)$

Suggestions for puskesmas are expected to create a limited club or class for fathers or husbands to facilitate the implementation of counseling about family planning and facilitate the counseling process for husbands about male contraceptives

Keywords: factor factor, Contraceptives of husbands.

\section{ABSTRAK}

Latar Belakang Program Keluarga Berencana (KB) sudah ditetapkan sejak tahun 1970, bersamaan dengan dibentuknya Badan Koordinasi Keluarga Berencana Nasional (BkkbN). Jumlah peserta KB aktif pada suami di Provinsi Lampung cenderung rendah yaitu 0,74\% pada MOP dan 1,95\% pengguna kondom. Angka pengguna kontrasepsi pada suami di Puskesmas Pinang Jaya hanya 0,3\%.

Tujuan penelitian ini adalah diketahui factor factor yang mempengaruhi pengguna alat kontrasepsi pada suami di Puskesmas Pinang Jaya Kota Bandar Lampung tahun 2018.

Metode yang digunakan dalam penelitian ini adalah observasional analitik dan desain cross sectional. Populasi adalah Pasangan Usia Subur (PUS) di Puskesmas Pinang Jaya sebanyak 987. Sampel dihitung sebanyak 312. Tehnik pengumpulan data menggunakan kuesioner dan analisis data menggunakan chi square dan regresi logistik berganda yang diolah dengan program komputer.

Hasil penelitian Univariat menunjukkan penggunaan alat kontrasepsi pada suami di Puskesmas Pinang Jaya Kota Bandar Lampung 44,2\%, pengetahuan baik 50,6\%, sikap positif 45,5\%, pendidikan tinggi $60,3 \%$, Hasil uji bivariat menunjukkan ada pengaruh pengetahuan ( $p=0,000 ; \mathrm{OR}=7,77)$, sikap $(\mathrm{p}=0,000 ; \mathrm{OR}=8,01)$, pendidikan $(p=0,000 ; O R=5,96)$, dengan penggunaan alat kontrasepsi pada suami.

Kesimpulan Faktor paling dominan berpengaruh dengan penggunaan alat kontrasepsi pada suami di Puskesmas Pinang Jaya Kota Bandar Lampung adalah variabel pengetahuan $(p=0,000$ dan $O R=4,380)$

Saran Bagi puskesmas di harapkan Membuat klub terbatas atau kelas ayah atau suami untuk memudahkan pelaksanaan penyuluhan tentang KB dan memduahkan proses konseling suami tentang alat kontrasepsi pria KB Pria

Kata Kunci: faktor factor, Alat kontrasepsi suami; 


\section{Endang Murniasih}

\section{PENDAHULUAN}

London Summit on Family Planning 2012 menghasilkan komitmen Family Planning 2020 yang keputusannya memperjuangkan semua perempuan untuk mendapatkan akses kontrasepsi di tahun 2020 dan memastikan setiap individu mendapatkan akses layanan kesehatan reproduksi secara gratis di tahun 2030 sebagai pendorong pencapaian Sustainable Development Goals (SDGs) (BkkBN, 2017)

Menurut Word Health Statistics 2013, penggunaan kontrasepsi di negara negara ASEAN (Association Of South East Asia) tertinggi pertama adalah Thailand $80 \%$, kemudian Kamboja $79 \%$, Vietnam $78 \%$, Indonesia $61 \%$, Filiphina $49 \%$, Laos $38 \%$ dan terendah adalah Timor Leste yaitu 22\%.(KEMENKES RI, 2014a)

Menurut World population data sheet 2013, dijelaskan bahwa Indonesia merupakan Negara ke5 di dunia dengan estimasi jumlah penduduk terbanyak yaitu 249 juta di antaranya negara ASEAN lainya. Indonesia dengan luas wilayah terbesar tetap menjadi negara dengan penduduk terbanyak, jauh di atas 9 negara anggota lain dengan angka fertilitas atau total fertility rate sebesar 2,6 yang berarti di atas rata rata fertility rate negara ASEAN yaitu 2,4. (KEMENKES RI, 2014b)

Sejalan dengan semangat International Conference on Population and Development (ICPD) 1994 di Cairo, pendekatan pelayanan kontrasepsi di Indonesia memegang teguh prinsip prinsip hak asasi manusia. Prinsip prinsip ini di terjemahkan dengan memberikan kebebasan yang bertanggung jawab bagi pasangan untuk menentukan jumlah, penjarangan dan pembatasan kehamilan serta informasi dan cara untuk memenuhi hak hak reproduksi tersebut baik untuk laki-laki ataupun perempuan. (KEMENKES RI, 2014a)

Keluarga Berencana (KB) pertama kali ditetapkan sebagai program pemerintah pada tanggal 29 Juni 1970, bersamaan dengan di bentuknya Badan Koordinasi Keluarga Berencana Nasional. Program KB di Indonesia sudah dimulai sejak tahun 1957. Namun masih menjadi urusan kesehatan dan belum menjadi urusan kependudukan. Namun sejalan dan semakin meningkatnya jumlah penduduk Indo nesia serta tingginya angka kematian ibu dan kebutuhan akan kesehatanreproduksi, Program KB selanjutnya di gunakan sebagai salah satu cara untuk menekan pertumbuhan jumlah penduduk serta meningkatnya kesehatan ibu dan anak. (KEMENKES RI, 2014b)

Data Survey Demografi Kesehatan Indonesia (SDKI) 2017 menunjukan tren prevalensi penggunaan kontrasepsi di Indonesia sejak tahun 1991-2017 cenderung meningkat untuk kontrasepsi yang digunakan wanita, Tren ini menggambarkan bahwa meningkatnya cakupan wanita usia 15-49 tahun yang melakukan KB sejalan dengan menurunnya angka fertilitas nasional.Sedangkan penggunaan alat kontrasepsi pada pria cenderung stagnan dan tidak signifikan memberikan kontribusi terhadap angka Contraceptive Prevalence Rate (CPR) atau Total Fertility Rate. (Bkkbn, 2001)

Data Badan kependudukan dan keluarga Berencana Nasional (BkkbN) 2017) menunjukan bahwa penggunaan kontrasepsi bulan Desember 2017 berjumlah 35.823 .514 peserta. Pengguna tertinggi adalah Jawa Barat $(6.930 .849)$ dan terendah Kalimantan Utara (38.325), Lampung nomor urut terbanyak ke 8 yaitu (1.298.283) namun jika dilihat dari penggunaan alat kontraspesi maka kontrasepsi pria menunjukkan angka yang paling rendah, misalnya kondom, hanya $(3,0 \%)$ sedangkan MOP $(0,6 \%)$. Fakta ini menunjukkan terjadi kesenjangan pengguna kontrasepsi pria dan kontrasepsi wanita dalam proses implementasi program KB. Ini menunjukan partisipasi laki laki dalam menggunakan alat kontrasepai masih sangat kecil. Penggunaaan alat kontrasepsi masih dominan di lakukan oleh perempuan. (Bkkbn, 2017)

Pencapaian Cakupan peserta KB aktif di Provinsi Lampung pada Tahun 2017, dari 1,7 juta Pasangan Usia Subur (PUS) yang menjadi pengguna aktif, adapun presentase KB Aktif berdasarkan penggunaan alat kontrasepsi pada suami diketahui MOP dan kondom masing masing hanya $(0,74 \%)$ dan $(1,95 \%)$.(Bkkbn, 2008)

Berdasarkan Data 2015 pencapaian akseptor Keluarga Berencana (KB) aktif menurut jenis kontrasepsi di perkecamatan di Kota Bandar Lampung dari 30 Puskesmas di wilayah Kota Bandar Lampung paling rendah dalam penggunakaan alat kontarsepsi kondom adalah Wilayah Puskesmas Sumur Batu pengguna kondom 13 orang $(0,4 \%)$ dan Susunan Baru 18 orang $(0,9 \%)$ serta di wilayah Puskesmas Pinang Jaya 3 orang $(0,3 \%)$ Menurut (Green, n.d.) perilaku kesehatan seperti partisipasi pria dalam ber- KB dapat menggunakan pendekatan faktor perilaku, dipengaruhi oleh 2 faktor pokok, yakni faktor perilaku (behavior causes) dan faktor di luar perilaku (non-behaviour causes). Selanjutnya perilaku itu sendiri ditentukan atau terbentuk dari 3 faktor; yaitu faktor predisposisi, yang terwujud dalam pengetahuan, sikap, kepercayaan, keyakinan, nilai-nilai, dan sebagainya. Faktor pendukung (enabling factors), yang terwujud dalam fasilitas-fasilitas atau sarana-sarana, alat-alat 
JKM (Jurnal Kebidanan Malahayati),Vol 7,No.3.Juli 2021,

ISSN (Print) 2476-8944 ISSN (Online) 2579-762X, Hal 413-420

kontrasepsi, dan sebagainya dan faktor pendorong (reinforcing factors) yang terwujud dalam sikap dan perilaku petugas kesehatan atau petugas lain, yang merupakan kelompok referensi dari perilaku masyarakat, diantaranya faktor predisposisi berupa factor utama terhadap perilaku yang menjadi dasar atau motivasi bagi perilaku. Berdasarkan fakta dalam latar belakang di atas peneliti tertarik untuk mengetahui tentang faktor-faktor yang berhubungan dengan pengguna alat kontrasepsi pada suami di Puskesmas Pinang Jaya Kota bandar lampung tahun 2018.

\section{METODOLOGI PENELITIAN}

Jenis penelitian yang di gunakan dalam penelitian ini adalah penelitian kuantitatif dengan desain observasional analitik, dan menggunkan metode pendekatan cross sectional yang bertujuan untuk mengetahui informasi yang mendalam tentang rendahnya pasrtisipasi suami menjadi akseptor KB Waktu penelitian ini dilaksanakan pada bulan Juni-Juli Tahun 2018 di wilayah Puskesmas Pinang Jaya kota Bandar Lampung. Populasi dalam penelitian ini adalah semua Pasangan Usia Subur (PUS) yang bertempat tinggal di wilayah Puskesmas Pinang Jaya berjumlah 987.dan sampel yang digunakan dalam penelitian ini adalah sebesar 297 ditambah 10\% dari minimal sampel untuk meminimalisir sampel yang drop out sehingga sample penelitian sebesar 312 suami. Teknik pengambilan sampling yaitu dengan total accidental sampling.

\section{HASIL DAN PEMBAHASAN Univariat}

Diketahui bahwa dari 312 responden yang ada di Wilayah Kerja Puskesmas Pinang Jaya Kota
Bandar Lampung terdapat sebanyak 174 responden $(55,8 \%)$ tidak berpatisipasi menjadi akseptor KB, sedangkan sebanyak 138 responden $(44,2 \%)$ adalah akseptor KB, terdapat sebanyak 154 responden $(49,4 \%)$ memiliki pengetahuan kurang, dan sebanyak 158 responden $(50,6 \%)$ memiliki pengetahuan baik.

Tabel 1.

Distribusi Frekuensi Responden

\begin{tabular}{|c|c|c|}
\hline Variabel & $\mathrm{n}$ & $\%$ \\
\hline \multicolumn{3}{|l|}{ Pengqunaan Alkontrsepsi } \\
\hline Tidak & 174 & 55,8 \\
\hline Ya & 138 & 44,2 \\
\hline \multicolumn{3}{|l|}{ Pengetahuan } \\
\hline Kurang & 154 & 49,4 \\
\hline Baik & 158 & 50,6 \\
\hline \multicolumn{3}{|l|}{ Sikap } \\
\hline Negatif & 142 & 45,5 \\
\hline Positif & 170 & 54,5 \\
\hline \multicolumn{3}{|l|}{ Pendidikan } \\
\hline Rendah & 124 & 39,7 \\
\hline Tinggi & 188 & 60,3 \\
\hline Total & 312 & 100,0 \\
\hline
\end{tabular}

Gambaran sikap 312 responden diketahui bahwa responden yang memiliki sikap positif sebanyak 142 responden (45,5\%),dan sebanyak 170 responden $(54,5 \%)$ memiliki sikap negatif. Adapun responden yang berpendidikan rendah sebanyak 124 responden (39,7\%) berpendidikan rendah dan terdapat 188 responden $(60,3 \%)$ berpendidi kan tinggi.

\section{Bivariat}

Tabel 2

Faktor-faktor yang Berhubungan dengan Pengguna Alat Kontrasepsi pada Suami

\begin{tabular}{|c|c|c|c|c|c|c|c|c|}
\hline \multirow{3}{*}{ Pengetahuan } & \multicolumn{4}{|c|}{ Penggunaan Alat Kontrasepsi } & \multirow{2}{*}{\multicolumn{2}{|c|}{ Total }} & \multirow{3}{*}{$p$ value } & \multirow{3}{*}{ OR $95 \% \mathrm{Cl}$} \\
\hline & \multicolumn{2}{|c|}{ Tidak } & \multicolumn{2}{|c|}{ Ya } & & & & \\
\hline & $\mathbf{n}$ & $\%$ & $\mathbf{n}$ & $\%$ & $\mathbf{N}$ & $\%$ & & \\
\hline Pengetahuan & & & & & & & & \\
\hline Kurang & 122 & 79,2 & 32 & 20,8 & 154 & 100 & مחת & 7,77 \\
\hline Baik & 52 & 32,9 & 106 & 67,1 & 158 & 100 & 0,000 & $(4,66-12,96)$ \\
\hline Sikap & & & & & & & & \\
\hline & 115 & 81,0 & 27 & 19,0 & 142 & 100 & & 8,01 \\
\hline Negatit Postiti & 59 & 34,7 & 111 & 65,3 & 170 & 100 & 0,000 & $(4,74-13,54)$ \\
\hline Pendidikan & & & & & & & & \\
\hline Rendah & 99 & 79,8 & 25 & 20,2 & 124 & 100 & & 5,96 \\
\hline Tinggi & 75 & 39,9 & 113 & 60,1 & 188 & 100 & 0,000 & $(3,52-10,10)$ \\
\hline Total & 174 & 55,8 & 138 & 44,2 & 312 & 100 & & \\
\hline
\end{tabular}




\section{Endang Murniasih}

Analisis bivariat pada penelitian ini digunakan untuk mengetahui pengaruh pengetahuan, sikap, pendidikan dengan rendahnya partisipasi suami menjadi akseptor Keluarga Berencana (KB) di wilayah Pinang Jaya Kota Bandar Lampung Tahun 2018. Hasil analisis penelitian ini ada di table bagian atas.

Berdasarkan hasil penelitian, maka dapat diketahui bahwa responden yang mempunyai pengetahuan kurang dan tidak berpartisipasi sebagai akseptor KB berjumlah 122 orang $(79,2 \%)$ lebih banyak di banding responden yang mempunyai pengetahuan baik berjumlah 52 orang $(32,9 \%)$. Diperoleh nilai $p=0,000$, yang menunjukkan ada pengaruh pengetahuan dengan partisipasi suami menjadi akseptor Keluarga Berencana di wilayah kerja Puskesmas Pinang Jaya Kota Bandar Lampung Tahun 2018. Hasil perhitungan didapati nilai $\mathrm{OR}=7,77 \quad(4,66-12,96)$ menunjukkan bahwa responden yang memiliki pengetahuan kurang berpeluang sebesar 7 kali untuk tidak berpartisipasi sebagai akseptor KB dibandingkan responden yang memiliki pengetahuan baik.

Responden yang mempunyai sikap negatif dan tidak berpartisipasi sebagai akseptor KB berjumlah 115 orang $(81,0 \%)$ lebih banyak di banding responden yang mempunyai sikap positif berjumlah 59 orang $(34,7 \%)$. Nilai $p=0,000$, menunjukkan ada pengaruh sikap dengan partisipasi suami menjadi akseptor Keluarga Berencana di Wilayah Kerja Puskesmas Pinang Jaya Kota Bandar Lampung Tahun 2018. Hasil perhitungan didapati nilai $\mathrm{OR}=8,01 \quad(4,74-13,54)$ menunjukkan bahwa responden yang memiliki sikap negatif berpeluang sebesar 8 kali untuk tidak berpartisipasi menjadi akseptor KB dibandingkan responden yang memiliki memiliki sikap positif. Responden yang mempunyai pendidikan rendah dan tidak berpartisipasi sebagai akseptor KB berjumlah 99 orang $(79,8 \%)$ lebih banyak di banding responden yang mempunyai pendidikan tinggi berjumlah 75 orang $(39,9 \%)$. Nilai $p=0,000$ menunjukkan ada pengaruh pendidikan dengan partisipasi suami menjadi akseptor Keluarga Berencana di Wilayah Kerja Puskesmas Pinang Jaya Kota Bandar Lampung Tahun 2018. Hasil perhitungan didapati nilai $\mathrm{OR}=5,96 \quad(3,52-10,10)$ menunjukkan bahwa responden yang berpendidikan rendah berpeluang sebesar 5 kali untuk tidak berpartisipasi menjadi akseptor KB dibandingkan responden yang memiliki tingkat pendidikan tinggi.

\section{PEMBAHASAN}

Penggunaan Alat Kontrasepsi pada Suami Hasil analisis univariat menunjukkan bahwa sebanyak 174 responden $(55,8 \%)$ tidak berpatisipasi menjadi akseptor KB, sedangkan sebanyak 138 responden (44,2\%) adalah akseptor KB.. Hal tersebut mengindikasikan ahwa masih banyak reponden yang tidak enggunakan alat kontrasepsi.dapar bersifat langsung maupun tidak langsung. Partisipasi Pria secara langsung dilakukan dengan metode senggama terputus, metode pantang berkala, kontrasepsi kondom, vasektomi. Adapun partisipasi pria secara tidak langsung dalam program KB yaitu menganjurkan, mendukung atau memberikan kebebasan kepada pasangannya (istri) untuk menggunakan kontrasepsi Untuk menerapkan terhadap pandangan masyarakat mengenai kontrasepsi partisipasi pria menjadi akseptor KB tersebut maka diperlukan proses sosialisasi agar para para suami dapat mengetahui mengenai informasi tersebut, serta dapat menerimanya dengan baik. Sosialisasi dilakukan melalui penyuluhan langsung kepada masyarakat, melalui kunjungan atau homevisit, atau diberikan pada saat konseling bagi pria. Hal tersebut sejalan dengan pendapat (Sureni, 2012), yang menyatakan bahwa proses penerimaan dan pembuatan keputusan terhadap suatu ide baru pada individu secara sederhana dapat digambarkan melalui tahap- tahap: Mula-mula individu menerima informasi dan pengetahuan berkaitan dengan suatu ide baru. Individu minat untuk mengenal lebih jauh tentang ide baru, fase ini seharusnya digunakan petugas untuk membujuk guna bersedia menerima ide baru. Tergantung dari hasil persuasi petugas dan pertimbangan individu, maka dalam tahap decision dibuatlah Program keluarga berencana (KB) merupakan program yang dicanangkan pemerintah dengan tujuan mewujudkan keluarga kecil bahagia sejahtera yang menjadi dasar bagi terwujudnya masyarakat yang sejahtera melalui pengendalian kelahiran dan pertumbuhan penduduk di Indonesia (Lipetz, et.al, 2009). Program KB di Indonesia telah diakui namun secara gender partisipasi pria lebih sedikit dari pada kepesertaan wanita Menurut (Prawiroharjo, 2002), bahwa Pria masih terbatas bila di bandingkan dengan cara KB yang di tujukan pada wanita. Hal ini antara lain di sebabkan karena banyak faktor yang perlu di pertimbangkan jika di bandingkan dengan penyediaan kontrasepsi wanita keputusan untuk menerima atau menolak ide baru tersebut. Individu meminta dukungan dari lingkungannya atas keputusan yang telah diambilnya. Bila lingkungan memberikan dukungan positif maka perilaku baru tersebut dapat dipertahankan tetapi bila ada 


\section{JKM (Jurnal Kebidanan Malahayati),Vol 7,No.3.Juli 2021, ISSN (Print) 2476-8944 ISSN (Online) 2579-762X, Hal 413-420}

keberatan dari lingkungan terutama dari kelompok acuan, biasanya adopsi tidak jadi dipertahankan dan kembali pada perilaku semula.

Melalui pemberian informasi yang baik, maka dapat menambah informasi serta membuka pengetahuan para suami dalam menerima dan mempertimbangkan pengguna an alat kontrasepsi yang tidak semata mata dilakukan oleh wanita tetapi pria juga dapat menjadi akseptor KB. Program Keluarga Berencana yang dimaksudkan untuk membantu para pasangan dan perorangan dalam mencapai tujuan reproduksi mereka. Serta dapat mencegah kehamilan yang tidak diinginkan dan mengurangi insiden kehamilan beresiko tinggi, kesakitan dan kematian, membuat pelayanan yang bermutu, terjangkau, diterima dan mudah diperoleh bagi semua orang yang membutuhkan.

\section{Pengaruh Pengetahuan dengan Pengguna an Alat Kontrasepsi pada Suami}

Hasil penelitian menunjukkan bahwa pengetahuan responden di wilayah kerja Puskesmas Pinang Jaya Kota Bandar Lampung, diketahui 154 responden (49,4\%) memiliki pengetahuan kurang, dan sebanyak 158 responden $(50,6 \%)$ memiliki pengetahuan baik. Keterkaitan faktor pengetahuan tersebut juga dapat dilihat dari hasil bivariat penelitian bahwa ada hubungan pengetahuan dengan Penggunaan alat kontrasepsi pada suami di Puskesmas Pinang Jaya Kota Bandar Lampung Tahun 2018. $(p<\square(0,000<0,05)$.

Hasil penelitian ini sejalan dengan teori Green dalam (Notoatmodjo, 2007) bahwa pengetahuan adalah hasil pengindraan manusia, atau hasil tahu seseorang terhadap sesuatu melalui indera yang dimilikinya. Dengan sendirinya, pada waktu penginderaan sampai menghasilkan pengetahuan tersebut sangat dipengaruhi oleh intensitas perhatian dan persepsi terhadap objek. Pengetahuan seseorang biasanya dipengaruhi dari pengalaman yang berasal dari berbagai macam sumber, misalnya media massa, media elektronik, buku petunjuk, petugas kesehatan, media poster, kerabat dekat dan sebagainya. Pengetahuan ini dapat membentuk keyakinan tertentu sehingga seseorang berperilaku sesuai keyakinan tersebut.

Hasil penelitian ini sejalan dengan hasil penelitian yang dilakukan oleh (Santoso, 2016), menjelaskan adanya hubungan antara pengetahuan tentang partisipasi dalam KB $(p=0,009)$. Sementara dari hasil peneliti (Ekarini, 2015) juga menjelaskan hasil penelitiannya bahwa ada hubungan yang bermakna antara pengetahuan terhadap partisipasi KB pada pria $(p=0.001)$.

Berdasarkan penjelasan tersebut maka peneliti berpendapat bahwa responden yang berpengetahuan baik lebih banyak yang melakukan partisipasi atau sebagai akseptor KB dibandingkan responden dengan proporsi pengetahuan yang rendah. Hal tersebut dikarenakan dengan adanya pengetahuan yang lebih baik. Pada kondisi ini responden semakin terbuka untuk menjadi pengguna alat kontrasepsi, dengan adanya pengetahuan maka responden menjadi semakin memahami terhadap manfaat dari partisipasinya menjadi akseptor $\mathrm{KB}$, dengan demikian akan semakin meningkatkan kesadaran pria untuk menjadi akseptor KB dan partisipasi dalam program KB bukan hanya bagi wanita saja.

\section{Pengaruh Sikap dengan Penggunaan Alat Kontrasepsi pada Suami \\ Hasil penelitian menunjukan sikap} responden di Puskesmas Pinang Jaya Kota Bandar Lampung, sebanyak 142 responden (45,5\%) memiliki sikap positif, dan sebanyak

170 responden (54,5\%) memiliki sikap negatif. Adapun proporsi hasil bivariat menggambarkan bahwa responden yang memiliki sikap negatif terdapat sebanyak 115 responden $(81,0 \%)$ yang tidak berpartisipasi sebagai akseptor KB. Sedangkan dari 170 responden yang memiliki sikap positif tinggi sebanyak 111 responden $(65,3 \%)$ yang berpartisipasi sebagai akseptor KB. Hasil analisis chi square membuktikan bahwa ada Pengaruh sikap dengan penggunaan alat kontrasepsi pada suami di wilayah kerja Puskesmas Pinang Jaya Kota Bandar Lampung Tahun 2018 (p $<(0,000<0,05)$.

Penelitian ini sejalan dengan penelitian yang telah dilakukan oleh (Ekarini, 2015) dengan hasil penelitian bahwa ada hubungan yang bermakna antara sikap terhadap partisipasi pria dalam program KB ( $p=0.0001)$. Penelitian tersebut juga didukung oleh penelitian (Santoso, 2016) yang membuktikan adanya hubungan sikap terhadap partisipasi pria dalam mengikuti program KB $(p=0,009)$.

Hasil analisis didukung dengan teori Azwar, yang mendefinisikan bahwa sikap seseorang adalah predisposisi (keadaan mudah terpengaruh) untuk memberikan tanggapan terhadap rangsangan lingkungan, yang dapat memulai ataupun membimbing tingkah laku orang tersebut. Sikap juga mengemukakaan pengertian sebagai tendensi untuk memberikan reaksi yang positif (menguntungkan) atau negatif (tidak menguntungkan) terhadap orang-orang, obyek atau situasi-situasi tertentu. Karena itu sikap merupakan suatu tendensi untuk memberikan reaksi yang 


\section{Endang Murniasih}

bersifat emosional dalam arah tertentu. Sikap akan tersimpan dalam memori jangka panjang seseorang dan sikap inilah yang akan membantu dalam menghadapi suatu masalah (pilihan) dengan cara mengingat kembali bagaimana perasaan yang dimiliki dituangkan dalam sikap tersebut (Azwar S, 2015).

Berdasarkan penjelasan tersebut maka dapat dijelaskan bahwa pada sikap mencerminkan bagaimana seseorang merasakan sesuatu. Sikap merupakan faktor predisposisi terjadinya perilaku. Bila seorang mempunyai sikap positif terhadap partisipasi untuk menjadi akseptor KB maka perilakunya juga akan sejalan dengan sikapnya. Kepesertaan KB pria menjadi akseptor KB terdorong dari sikapnya. Adapun responden dengan sikap positif tetapi tidak menjadi akseptor KB disebabkan oleh banyak kemungkinan seperti penggunaan kontrasepsi yang sudah terlanjur dilakukan oleh pasangannya atau karena keputusan bersama sehingga membuatnya tidak menjadi akseptor KB. Adapun sikap negatif lahir karena banyak faktor misalnya adanya berbagai mitos terkait dengan dampak atau risiko penggunaan alat kontrasepsi pada pria. Salah satu mitos yang ada adalah vasektomi lebih dikenal dengan kebiri, jika laki-laki dikebiri maka dianggap hilang nafsu syahwatnya dan menjadi impoten. Informasi ini perlu diluruskan dan diklarifikasi agar sikap terbentuk secara proporsional.

\section{Pengaruh Pendidikan dengan Penggunaan Alat Kontrasepsi}

Proporsi tingkat pendidikan responden diketahui responden yang pendidikannya rendah terdapat sebanyak 99 responden $(79,8 \%)$ yang tidak berpartisipasi sebagai akseptor KB. Sedangkan dari 188 responden yang memiliki pendidikan tinggi sebanyak 113 responden $(60,1 \%)$ yang berpartisipasi sebagai akseptor KB. Analisis chi square menghasilkan nilai $p=0,000$ yang menunjukkan ada pengaruh pendidikan dengan partisipasi suami menjadi akseptor Keluarga Berencana di Wilayah Kerja Puskesmas Pinang Jaya Kota Bandar Lampung Tahun 2018.

Secara teori tingkat pendidikan dianggap penting karena dari pendidikan seseorang dapat mengetahui dan melaksanakan perannya sesuai dengan tujuan organisasi. Oleh karena itu temuan penelitian ini sejalan dengan teori Notoatmodjo bahwa pendidikan adalah upaya persuasi atau pembelajaran kepada masyarakat agar mau melakukan tindakan (praktik) untuk memelihara untuk mengatasi masalah-masalah dan untuk meningkatkan kesehatannya. Perubahan atau tindakan pemeliharaan dan peningkatan kesehatan yang dihasilkan oleh pendidikan kesehatan ini di dasarkan pada pengetahuan dan kesadaranya melalui proses pembelajaran. Sehingga perilaku tersebut diharapkan akan berlangsung lama (long Lasting) dan menetap (langgeng) karena di dasari oleh kesadaran (Notoatmodjo, 2012).

Hasil penelitian ini sejalan dengan hasil penelitian Lestari tahun 2010 yang menyimpulkan adanya hubungan pendidikan dengan tingkat partisipasi suami dalam menggunakan KB $(p=0,002)$ (Lestari, 2010).

\section{Faktor Dominan Penggunaan Alat Kontrasepsi}

Hasil keseluruhan proses analisis multivariate yang telah dilakukan dapat disimpulkan bahwa dari beberapa faktor yang berhubungan dengan penggunaan alat kontrasepsi pada suami terdapat variabel yang paling dominan yaitu variabel pengetahuan karena variabel ini memiliki nilai $p$ paling kecil $(0,000)$ dan nilai OR paling besar $(4,380)$ dibandingkan variabel lainnya. Artinya responden yang pengetahuannya tinggi berpeluang untuk berpartisipasi menjadi akseptor KB sebesar 4 kali dibandingkan responden yang pengetahuannya rendah.

Pengetahuan merupakan kumpulan informasi yang didapatkan oleh seseorang setelah melakukan penginderaan terhadap suatu objek. Pengetahuan mengenai suatu hal menyebabkan seseorang melakukan kegiatan yang berkaitan dengan yang diketahuinya. Oleh karena itu, pengetahuan merupakan ranah yang sangat penting dalam pembentukan perilaku seseorang.

Hal ini sesuai dengan penelitian di Situbondo (Putro, 2013) yang menunjukkan bahwa pengetahuan responden yang baik 5,4 kali memungkin kan responden untuk berpartisipasi dalam program KB. Pengetahuan seseorang terhadap suatu objek dapat berubah dan berkembang sesuai dengan pengalaman dan tinggi rendahnya mobilitas informasi tentang objek tersebut di lingkungannya.

Pengetahuan seseorang secara otomatis tidak dapat merubah perilakukanya. Langkah intervensi yang dapat dilakukan adalah dengan memberikan informasi dan penyuluhan baik yang bersifat komunal maupun personal secara terus menerus kepada suami sehingga dapat memperoleh informasi yang lengkap dan detail tentang penggunaan alat kontrasepsi pada suami. Materi yang diberikan seharusnya bersifat praktis termasuk langkah-langkah penggunaan alat kontrasepsi pada suami, sehingga informasi yang diperoleh suami secara utuh. Berdasarkan 


\section{JKM (Jurnal Kebidanan Malahayati),Vol 7,No.3.Juli 2021, ISSN (Print) 2476-8944 ISSN (Online) 2579-762X, Hal 413-420}

penjelasan tersebut maka penulis berpendapat bahwa meskipun ada hubungan antara pengetahuan dengan penggunaan alat kontrasepsi pada suami namun pengetahuan yang diperoleh tidak secara otomatis dapat merubah perilakukanya, dan membutuhkan pengetahuan yang terus menerus sehingga masyarakat akan lebih memahami dan mampu menjadi dorongan tersendiri untuk merubah perilaku kesehatannya.

Pengetahuan menjadi faktor penting dalam membentuk perilaku penggunaan alat kontrasepsi pada suami. Oleh karenanya program stimulasi yang dapat membentuk pengetahuan perlu dilakukan dalam bentuk kegiatan promosi kesehatan baik yang bersifat formal atau non formal. Kegiatan formal dapat dilakukan dengan membuat kelas ayah yang dibentuk semacam klub atau komunitas yang terkait dengan informasi kesehatan khusus untuk suami. Kegiatan sosialisasi juga dapat dilakukan dengan menyebarkan informasi tentang alat kontrasepsi pria melalui poster, leaflet dan lain sebagainya. Bekerjasama untuk menjalankan program $\mathrm{KB}$ di media radio untuk memberikan kesempatan informasi dan konsultasi.

Untuk menjangkau dan menklarifikasi informasi keliru tentang KB maka perlu dilakukan upaya dengan membuat klub terbatas atau kelas ayah atau suami untuk memudahkan pelaksanaan penyluhan tentang KB dan memduahkan proses konseling suami tentang alat kontrasepsi pria KB Pria. Perlu juga mencetak brosur atau leaflet tentang anuran partisipasi suami dalam ber $\mathrm{KB}$ melalui informasi yang benar. Menyiarkan program KB melalui siaran radio untuk dapat menjangkau masyarakat di daerah dan memudahkan mereka mendapatkan informasi tentang KB pria. Pelayanan $\mathrm{KB}$ juga harus dikondikan melalui penyediaan kondom gratis di setiap Puskesmas dan memfasilitasi program vasektomi dengan menyediakan mobil antar jemput dan pembiayaan gratis untuk vasektomi

Untuk meningkatkan pengetahuan para suami maka perlu dukungan petugas kesehatan Khususnya PLKB melalui optimalisasi pelayanan petugas kesehatan kepada akseptor KB salah satunya dengan memberikan motivasi dan konsultasi kepada suami untuk menjadi akseptor KB. Masyarakat perlu memahami dan menambah informasi berkaitan dengan partsisipasi pria dalam program KB dengan mengakses info di media elektoronik misal HP sehingga pelaksanaan KB tidak bias gender dan mematahkan stigma bahwa penggunaan kontrasepsi hanya untuk wanita saja.

Suatu perilaku yang didasari oleh pengetahuan akan lebih melekat dan tahan lama dibandingkan dengan perilaku yang tidak didasari oleh pengetahuan. Para suami yang lebih sering mendapatkan pendidikan kesehatan saat mempunyai pengetahuan yang lebih baik dibandingkan dengan yang para suami jarang mendapatkan pendidikan kesehatan tentang KB sehingga potensinya memperoleh informasi lebih luas dan tepat sasaran.

\section{SIMPULAN}

Faktor paling dominan berpengaruh dengan penggunaan alat kontrasepsi pada suami di Puskesmas Pinang Jaya Kota Bandar Lampung adalah variabel pengetahuan $(p=0,000$ dan $\mathrm{OR}=4,380$ )

\section{SARAN}

Bagi puskesmas di harapkan Membuat klub terbatas atau kelas ayah atau suami untuk memudahkan pelaksanaan penyuluhan tentang KB dan memduahkan proses konseling suami tentang alat kontrasepsi pria KB Pria,

Mencetak brosur atau leaflet tentang anuran partisipasi suami dalam ber KB melalui informasi yang benar, Menyiarkan program KB melalui siaran radio untuk dapat menjangkau masyarakat di daerah dan memudahkan mereka mendapatkan informasi tentang KB pria

Menyediakan kondom gratis di setiap Puskesmas dan memfasilitasi program vasektomi dengan menyediakan mobil antar jemput dan pembiayaan gratis bagi peserta yang ingin berpartisipasi vasektomi.

Bagi Masyarakat Untuk meningkatkan pengetahuan para suami maka perlu dukungan petugas kesehatan Khususnya PLKB melalui optimalisasi pelayanan petugas kesehatan kepada akseptor KB salah satunya dengan memberikan motivasi dan konsultasi kepada suami untuk menjadi akseptor KB.

Masyarakat perlu memahami dan menambah informasi berkaitan dengan partsisipasi pria dalam program $\mathrm{KB}$ dengan mengakses info di media elektoronik misal HP sehingga pelaksanaan KB tidak bias gender dan mematahkan stigma bahwa penggunaan kontrasepsi hanya untuk wanita saja.

Menyediakan Waktu untuk melibatkan diri mencari informasi bersama istri ke tempat pelayanan $\mathrm{KB}$

\section{DAFTAR PUSTAKA}

Akbaretal, (2015) dukungan Tokoh Masyarakat dalam Keberlangsungan Desa Siaga Aktif 


\section{Endang Murniasih}

didesa Kenongo Kecamatan Gucialit Kabupaten Lumajang:e-Jurnal Pustaka Kesehatan, vol. 3 (no. 3) .

Alus, R(2012).Faktor yang berhubungan dengan penggunaan metode kontrasepsi jangka panja diwilayah kerja puskesmas Pancoran Mas Depok, Skripsi.Depok: Universitas Indonesia.

Adriani,Loli(2015).Determinan partisipasi penggunaan kontrasepsi modern pada pria kawin usia 15-54 tahun di indonesia ( Analisis data survey demografi dan kesehatan indonesia 2012)

Azwar S. (2015). Sikap Manusia Teori dan Pengukrannya (Edition ke 2). Yogyakarta: Pustaka Pelajar.

Bkkbn. (2001). Partisipasi Pria dalam KB dan Kesehatan Reproduksi. Jakarta.

Bkkbn. (2008). Faktor - faktor mempengaruhi rendahnya partisipasi pria dalam $\mathrm{Kb}$. Retrieved from Bkkbn.go.id.

Bkkbn. (2017). Analisis dan Evaluasi pengendalian program dan anggaran. Jakarta: Direktor Pelapor dan Statistik.

BkkBN. (2017). Komitmen pemerintah indonesia di FP 2020 dan Perkembangannya, PKBI.

Ekarini. (2015). Analisis Faktor - faktor yang berpengaruh terhadap partisipasi pria dalam KB kecamatan Solo Kabupaten Boyolali. Tesis FKM Undip Semarang.

Green. (n.d.). Modifying And Developing Health Behaviour, Center For Health Promotion Research and Development, the university of Texas, Health Science Center at Houston, 22.

KEMENKES RI. (2014a). Infodatin KB situasi dan analisis keluarga berencana. Jakarta.

KEMENKES RI. (2014b). Pedoman manajemen keluarga berencanapenyakit kandungan. Jakarta.
Lestari. (2010). Analisis Respon masyarakat desa terhadap program KB oada pria dalam rangka peningkatan kualitas sumber daya manusia di desa Cihindeung udik Kabupaten Bogor. Retrieved from Dikti.go.id

Minarni (2009) Determinan kepesertaan pria dalam Kb Di Kota Paga rAlam Propinsi Sumatra Selatan Tahun 2009

Notoatmodjo, S. (2007). Promosi Kesehatan dan prilaku kesehatan. Jakarta;Renika Cipta.

Nurlina,Reni(2011),Analisis Partisipasi Pria Sebagai Akseptor KB (Kondom Dan Vasektomi)diWilayahKerjaPuskesmasCipana $s$ Kecamatan Cipanas Kabupaten lebak Provinsi Banten 2011.

Notoatmodjo, S. (2012). Promosi Kesehatan dan Perilaku Kesehatan. Jakarta;Renika Cipta.

Prawiroharjo. (2002). IImu Kebidanan. Jakarta;Yayasan Bina Pustaka.

Putro. (2013). Faktor sosial budaya dan pelayanan kontrasepsi yang berkaitran dengan kesertaan KB pria diKecamatan Gembong Kabupaten Kebumen.

Santoso, B. (2016). Isue Gender dalam kesehtan reproduksi pusat pelatihan gender dan peningkatan kualitas perempuan, BKKBN. Jakarta.

Sureni. (2012). Study Gender Peranan Pria dalam penggunaan kontasepsi di propinsi DIY, Kanwil BKKBN DIY dan PSW UMY, Yogyakarta.

Saptalia,Nunik(2016). Faktor yang mempengaruhi pemilihan metode kontrasepsi, Jurnal Biomedik dan Kependudukan, uiversitas Airlangga

Winarti, (2010) Factor Factor Yang Mempengaruhi Partisipasi Pria DalamBerkontrasepsi Vasektomi Di Wilayah Kerja Puskesmas Pancoran Mas DepokTahun 2010. 